\title{
The Impact of Service Climate and Job Satisfaction on Service Quality in a Higher Education Platform
}

\author{
Dr. Abu Rashed Osman (Corresponding author) \\ School of Business \& Economics, United International University, Bangladesh \\ Tel: 880-181-991-0688Ｅ-mail: rash_osman@yahoo.com \\ Jashodhan Saha, Senior Lecturer \\ Institute of Natural Science, United International University, Bangladesh \\ E-mail: jasha@ins.uiu.ac.bd \\ Mirza Mohammad Didarul Alam, Assistant Professor \\ School of Business \& Economics, United International University, Bangladesh \\ E-mail:mirza@bus.uiu.ac.bd
}

Received: March 12, 2017 Accepted: May 29, 2017 Published: July 14, 2017

doi:10.5296/ijld.v7i3.10926 URL: https://doi.org/10.5296/ijld.v7i3.10926

\begin{abstract}
This study examines service climate and service quality through the mediating impact of job satisfaction within a tertiary education level in Bangladesh. The sample size of the study consisted of 140 faculty-members from four different private universities of Dhaka city and a structured questionnaire was designed to assess the service quality of higher education. Several statistical methods such as t-test, correlations and multiple-regression were used to analyze the data. The study discloses that the overall service climate has a significant positive impact on service quality. Finally, the study reveals that job satisfaction is partially mediating between service climate and service quality. This paper makes an outstanding empirical contribution by incorporating service climate and job satisfaction and exploring their relationships with service quality in the context of higher education. The overall results of this study would be
\end{abstract}




\section{Macrothink}

International Journal of Learning and Development

ISSN 2164-4063 2017, Vol. 7, No. 3

valuable to the planners to formulate the pragmatic strategies for ensuring service quality through service climate and job satisfaction of faculty-members in the private tertiary level institutions. This is one of the rare empirical studies in this sector, and thus represents a unique contribution to the literature.

Keywords: Service climate, job satisfaction, service quality, and higher education 


\section{Introduction}

Service quality is usually considered as a customer's evaluation of the service (Kandampully et al., 2011). Service quality is viewed as a critical success factor of service organization (Avcikurt et al., 2011). Several factors have been identified as influencing service quality but two vital categories are: employee factors and organizational factors. Considering the employee factors, a number of studies revealed that employees' job behavior (Morrison, 1996), job satisfaction (Glisson \& Hemmelgarn, 1998), and organizational commitment (Hung, 2006) had a positive influence on service quality.

However, many studies highlighted organizational factors as more essential determinant of service quality. The organizational factors that have an influence on service quality are support from management and supervisors, positive work group relationships (Batt, 1999) and team culture (Glisson \& James, 2002). Manning et al. (2005) also indicated that employees in service sectors often represented the crossing point between organization and customers; thus the organizational climate was essential in supporting the employees to be responsible for a quality service. This study incorporated both the employee and organizational factors such as; service climate and job satisfaction of faculty members.

Employees are vital resources in the operations of a successful business entity. They are working in the transformational process and adding value to product/service (Davidson, 2003).To create and retain right human resources, organizational climate works as a tool that helps management to realize the overall sense of service quality. He et al. (2011) mentioned that a common theme in service marketing literature was that organizations must create and maintain a climate to encourage employees to effectively deliver excellent service. Lovelock (2001) pointed out many initiatives in quality were taken but most of them were failed due to their objectives. Thus, arguments that quality initiatives without understanding an organization's climate are always inclined to failure. Schneider et al. (1994) emphasized that organizations needed to be conscious of three separate kinds of organizational climate in order to ensure the success of quality improvement efforts: a climate for service, a climate for innovation, and a climate for employee welfare. Davidson (2003, p209) pointed out if a good organizational climate existed for service, simply it provided the best possible atmosphere for quality service to deliver. Schneider, White, and Paul (1998) mentioned that service climate itself depends on a strong foundation - a suitable environment upon which a service climate could be built. Such an environment is characterized by well-trained employees who have the tools that they require to perform their jobs, have the opportunity to participate in decisions affecting how they perform their work, and receive the service and support they need from other organizational members so that they are able to serve customers well.

Previous studies had provided useful empirical insights for conceptualizing service climate. However, due to the uniqueness of higher educational environment, the dynamic relations between service climate and service quality need to be explored. Boo et al. (2009) mentioned that more empirical investigations on service climate could be performed on specific service sector such as higher education, hospitality and so forth. A little research has done on service climate and service quality through mediating impact of job satisfaction in higher education. 
Specially, this study is rare in Bangladesh private-university perspective. This motivates authors to conduct a research to what extent service climate and job satisfaction influence on service quality of education. Furthermore, in Bangladesh private university context several researchers claimed that service quality of education in private universities was not satisfactory due to the overall service climate of the institutions (Monem \& Baniamin, 2010; Mohsin \& Kamal, 2012; Rouf et al., 2015; and Salauddin \& Aminuzzaman, 2011). Service climate is proposed to have three major components in this study, including customer orientation, managerial support and work facilitation.

\section{Conceptual Framework}

The current study illustrates a conceptual framework (Figure1) which theoretically grounded on Social Exchange Theory that defined for the each variable. It provides a rational to comprehend the influence of service climate on individual behavior. Visualizing the social exchange theory, employees reciprocate benefits received in such a way that they return benefits to the exchange partners (Blau, 1964). Service climate releases the internal social exchange relationship between employees and the organization. When employees perceive the organization expects, supports and rewards service quality, they believe their work roles are valued and their contributions are cared about. Thus, they incline to reciprocate the favorable treatment with positive behaviors according to the norm of reciprocity (Gouldner, 1960). Empirical finding has made visible the positive relationship between service climate and in-role service performance (Liao \& Chuang, 2004).

\section{Literature Review and Hypothesis Development}

\subsection{Service Climate}

Service climate is defined as "the shared perceptions of employees concerning the practices, procedures, and kinds of behaviors that get rewarded and supported with respect to customer service and service quality (Schneider et al., 1998, p-151). Francese (1993) found that there was a link between service quality and organizational climate. The climate of the organization was an important factor in the creation of quality services. Cole et al. (1993) claimed that without a proper environment it was difficult to acquire the employee's support for the objectives of management. The participation of service climate in service organizations is related with creating good ideas, efficient delivery of service quality (Dietz et al., 2004). Schneider et al. (1998) argued that the way employees perceive the service climate in their organizations was positively related to customer satisfaction and service quality. Service organizations those are conscious about service climate and concern about employee satisfaction, ultimately employees of those organizations are most probably willing to stay longer in the organizations and committed to serve the organizations (Boo et al., 2009). Furthermore, in service quality literature found that organizations must create and maintain a climate for service that encouraged employees to deliver excellent service effectively. Thus, the hypothesis can be drawn in this manner:

H1: There is a significant positive impact of overall service climate on service quality. 


\subsection{Service Climate and Job satisfaction}

Singh et al. (2011) indicated that positive climate enhanced the job satisfaction level of the employees. Peek (2003) conducted a study on institutional research and the study concluded that organizational climate and research satisfaction had positively and significantly correlated. The faculty's high level of satisfaction with organizational climate factors had found significant (Sofianos, 2005). Sargunam and Rathnamala (2014) conducted a study in higher education context and revealed that organizational climate was positively related to job satisfaction of the faculties. Moreover, reward system, career development, and teamwork \& support dimensions of organizational climate were more responsible for explaining variance in dependent variable (job satisfaction). Therefore, hypothesis can be drawn in this manner:

\section{H2: There is a significant positive impact of service climate on job satisfaction.}

\subsection{Job satisfaction and Service Quality}

Nancarrow (2007) revealed that high job satisfaction created obligation for providing superior service and increased autonomy. Umar (2015) showed that job satisfaction significantly affecting performance of the organization. Robbins (2001) pointed that satisfied employees were prerequisite for improving productivity, quality, and customer service. Several studies pointed out that job satisfaction was significantly connected with service quality (Evanschitzky et al., 2011; Gazzoli et al., 2010; and Kim et al., 2009). A recent meta-analysis also revealed that job satisfaction accounted for between six to ten percent of total variance in service quality (Brown \& Lam, 2008). The possible explanation is that highly satisfied employees might be more enthusiastic to participate with positive and helpful attitudes that lead to superior quality (Lee et al., 2006). Thus, based on the discussion, the following hypothesis is established:

\section{H3: There is a significant positive impact of job satisfaction on service quality.}

\subsection{Job Satisfaction Mediates between Service Climate and Service Quality}

Employees are the most precious capital of an organization. Therefore, establishing the positive behavior of employees is essential for management keeping excellence in service quality. In fact, service climate is one of the influential factors that can influence motives, efficiency, and job satisfaction (Khoshnoud, 2011).Two past studies (Saffari et al., 2010; and Delgoshyay et al., 2008) revealed that it was not the policies, plans, and financial position of an organization that made a suitable environment for work. What creates a suitable and desirable working atmosphere is the feelings of employees have towards their working environment.

Several previous studies of employees in various sectors such as hotels (Kim et al., 2009), banking (Malthotra \& Mukherjee, 2004), restaurant (Gazzoli et al., 2010) and franchise services (Evanachitzky et al., 2011) all presented that job satisfaction was positively related to service quality.

Based on above discussion, the present study concludes that service climate has a positive 


\section{Macrothink}

International Journal of Learning and Development

ISSN 2164-4063 2017, Vol. 7, No. 3

relationship with job satisfaction and in turn job satisfaction influences service quality. These viewpoints are quite good and sufficient to establish the mediation effect (Kenny et al., 1998). Consequently, this study proposes that job satisfaction can occupy the position of mediating variable between service climate and service quality. Steinke (2008) also indicated that job satisfaction partially mediated the relationship between service climate and service quality. However, till date, there is still deficiency of empirical evidence whether job satisfaction mediates the relationship between service climate and service quality, particularly in the context of private higher education in Bangladesh. Hence, the hypothesis can be established in this manner:

H4: Job satisfaction mediates the relationship between service climate and service quality.

\section{Proposed Model}

\section{Service Climate Dimensions}

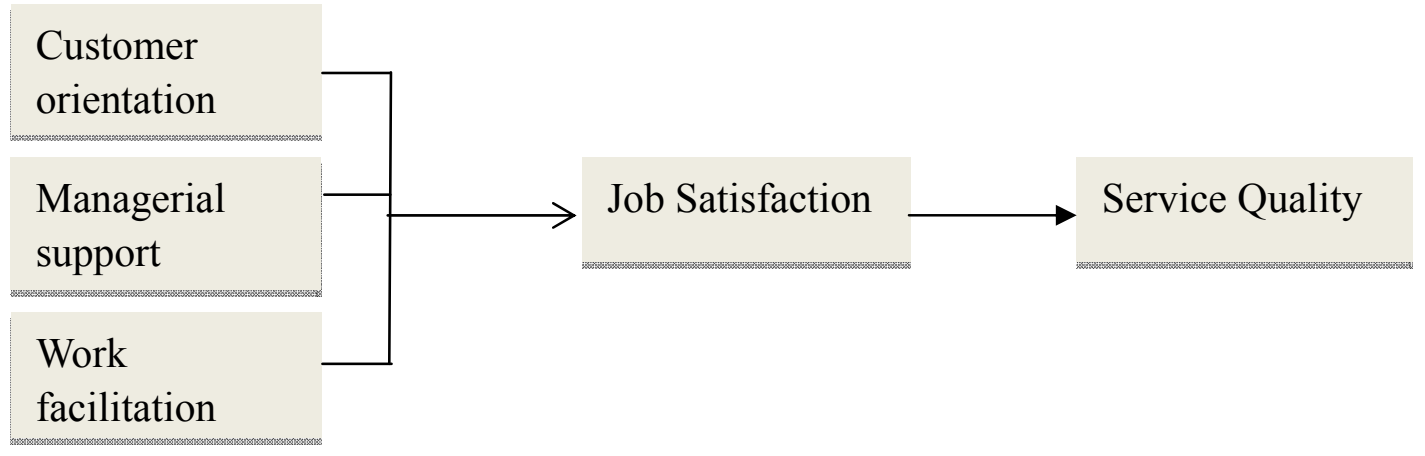

Figure 1. Conceptual Model for Service Climate and Service Quality

\subsection{Hypotheses}

H1: There is a significant positive impact of overall service climate on service quality.

H2: There is a significant positive impact of overall service climate on job satisfaction.

H3: Job satisfaction has a significant positive effect on service quality.

H4: Job satisfaction is mediating between service climate and service quality. 
Table 1. Variables and Measurement Items in this Research

\begin{tabular}{lcc}
\hline Items & $\begin{array}{l}\text { Factor } \\
\text { Loading }\end{array}$ & $\begin{array}{c}\text { Cronbach's } \\
\text { Alpha }\end{array}$ \\
\hline Work Facilitation & & $\mathbf{0 . 6 7 1}$ \\
WF1: I receive adequate support from workmates to perform my job well. & 0.663 & \\
WF2: If I perform job well, I receive appropriate recognition and reward. & 0.782 & \\
WF3: I have the guidelines and resource materials available to serve my & 0.669 \\
job. & 0.719 \\
$\begin{array}{l}\text { WF4: I have access to the product and policy information when I need them } \\
\text { to do my work in my institution. }\end{array}$ & \\
\hline
\end{tabular}

\begin{tabular}{lc}
\hline Managerial Support & $\mathbf{0 . 8 8 1}$
\end{tabular}

MS1: My direct supervisor supports me when I come up with new ideas on $\quad 0.857$ how to improve service.

MS2: My direct supervisor encourages me to deliver high quality service. $\quad 0.858$

MS3: My direct supervisor is responsive to my requests for help or 0.866 guidance.

MS4: My direct supervisor is very committed to improving the quality of 0.857 our area's work and service.

\section{Customer Orientation}

CO1: My institution has clear ideas about students and their needs.

$\mathrm{CO} 2$ : High quality service is emphasized as the best way to keep students.

CO3: My institution defines its services from students' perspectives.

CO4: My institution does a good job of keeping students informed of changes, which affect them.

CO5: We are informed about student evaluations of the quality of service delivered.

CO6: My institution always responds to the students' feedback and suggestions quickly.

\section{Job Satisfaction}

JS1: I believe faculties of my university are well-trained.

JS2: I believe transparent performance evaluation system is in practice for staffs.

JS3: I believe performance based reward system is in practice.

JS4: I believe faculties are enjoying homely work environment.

JS5: I believe faculties are enjoying competitive compensation package.

JS6: I believe supervisors are more concern about faculties' performance.

JS7: I believe timely and unbiased promotion is a common practice of my university.

JS8: I believe faculties are enjoying job freedom. 


\section{Macrothink}

Table 2. Service Quality Dimensions and Its Measurement Items

\begin{tabular}{|c|c|c|}
\hline Items & $\begin{array}{l}\text { Factor } \\
\text { Loading }\end{array}$ & $\begin{array}{l}\text { Cronbach's } \\
\text { Alpha }\end{array}$ \\
\hline Tangibles & & 0.763 \\
\hline Tan 1: Modern teaching \& IT facilities & 0.789 & \\
\hline Tan 2: Appealing appearance & 0.832 & \\
\hline Tan 3: Faculties are exposing professional character & 0.675 & \\
\hline Tan 4: Interesting and understandable materials & 0.764 & \\
\hline Responsiveness & & 0.801 \\
\hline Res 1: Provides accurate information & 0.724 & \\
\hline Res 2: Provides prompt response & 0.786 & \\
\hline Res 3: Willing to provide academic assistance & 0.846 & \\
\hline Res 4:Improving students' personal \& communication skills & 0.810 & \\
\hline Assurance & & 0.775 \\
\hline Assur 1: Furnishing Professional skills & 0.759 & \\
\hline Assur 2: Worthy for quality education & 0.834 & \\
\hline $\begin{array}{l}\text { Assur 3: I am confident that administrative staffs are providing quality } \\
\text { services to students. }\end{array}$ & 0.755 & \\
\hline Assur 4: Academics are knowledgeable & 0.530 & \\
\hline Assur 5: Administrative staffs are courteous. & 0.715 & \\
\hline Reliability & & 0.839 \\
\hline Rel 1: Fair and consistent assessment & 0.640 & \\
\hline Rel 2: Sincere intention resolving problems & 0.865 & \\
\hline Rel 3: Fulfills students' requirements & 0.793 & \\
\hline Rel 4: Fulfills promises & 0.849 & \\
\hline Rel 5: Promotes error free records & 0.745 & \\
\hline Empathy & & 0.850 \\
\hline Emp 1: Staffs understand well challenges facing students & 0.837 & \\
\hline Emp 2: Well publicized convenient opening hours & 0.594 & \\
\hline Emp 3: Provides emergency services & 0.815 & \\
\hline Emp 4: Gives tailored advice to students & 0.831 & \\
\hline Emp 5: Staffs understand specific needs & 0.864 & \\
\hline
\end{tabular}

Note. Bold factor loadings are deleted for further analysis. 


\section{Research Method}

\subsection{Sample and Procedure}

The study presented in this current paper was conducted in Bangladesh in respect of private-university covering only Dhaka city because most of the private universities were located in Dhaka. Total of 160 structured questionnaires were distributed for data collection and four private universities were selected under this study those are in Dhaka city. These are United International University, Daffodil International University, Liberal Arts University, and Stamford University. In total of 142 questionnaires were returned and 140 found useable. Two samples were not considered and excluded from subsequent analysis due to the missing values and improper answers (Hartline \& Jones, 1996). Therefore, the total sample for this study was 140 . The respondents in this study were faculty-members of various schools and systematic random sampling technique had been used due to the easy access to list. Several previous studies measured service quality based on internal employees' perception (Cook \& Verma, 2002; Glisson \& James, 2002; and Slatten et al., 2011). Questionnaires were personally administered to all faculties employed in various universities. Confirmation from prior studies indicated that this technique produced higher response rates (Tay, 2008).

\subsection{Instrument}

The instrument employed to measure service quality comprised of 23 items and to measure service climate comprised of 14 items from various researches which are given below: Customer orientation (six items) adapted from Day (1994) and Shainesh \& Sharma (2003), alpha coefficient $=0.850$. Managerial support (four items) adapted from Foley and Hang (2005), alpha coefficient $=0.881$. Work facilitation (four items) adapted from Shainesh and Sharma (2003), alpha coefficient $=0.671$. Job satisfaction (eight items) adapted from Schnake (1983), alpha coefficient $=0.838$. Service quality (23 items) adapted from Parasuraman et al. (1988). Faculties were asked to assess the extent to which each one of the 41 statements applied to the university they were employed in, with a five-point Likert scale, ranging from 1 to 5.The average Cronbach's alpha for this scale is 0.805 .

\subsection{Data Analysis, Reliability and Validity}

Before performing regression analysis, the reliability of scales was measured by Cronbach's alpha. In this study, all values of Cronbach's alpha ranged from 0.671 to 0.881 (see Table I \& II). Usually, Cronbach's of 0.70 or above shows internal consistency of the established scales (Bagozzi \& Yi, 1988). Since most of the constructs were well-established in existing literature, the scales could be considered to possess content validity.

In order to achieve an uni-dimensionality, factor loading less than 0.60 needs to be deleted. Uni-dimensionality must be ensured before modeling their inter-relationship. The factor loading for an item should be 0.60 or higher for already established scales (Awang, p-33, 2013). In this study, factor loadings are ranged from 0.594 to 0.882 which are demonstrating uni-dimensionality (see Table $1 \& 2$ ) after deleting two items due to factor loading less than 0.60 . 


\section{Macrothink}

The assessment of normality was conducted through the value of skewness and must confirm the range of -1.0 to +1.0 to indicate normality (Awang, 2013). The Table 3 confirmed the normality. A few statistical techniques were used such as t-test, ANOVA, correlation, and multiple-regression. To verify the hypotheses, multiple-regression was conducted in this study.

Table 3.The Assessment of Normality

\begin{tabular}{llllc}
\hline Variables & Min & Max & Skewness & Kurtosis \\
\hline WF & 1.75 & 5.00 & -0.363 & 0.407 \\
MS & 1.00 & 5.00 & -0.537 & -0.161 \\
CO & 1.33 & 5.00 & -0.040 & -0.794 \\
JS & 1.38 & 5.00 & -0.263 & 0.015 \\
TAN & 1.25 & 5.00 & -0.405 & 0.321 \\
REL & 1.80 & 5.00 & -0.151 & -0.592 \\
RES & 2.00 & 5.00 & -0.309 & -0.455 \\
ASS & 2.00 & 5.00 & -0.297 & -0.346 \\
EMP & 1.60 & 5.00 & -0.175 & -0.157 \\
\hline
\end{tabular}

The value of skewness should fall within the range of -1.0 to 1.0 to indicate normal distribution. The value of kurtosis for the model all constructs should be lower than 50; otherwise the assumption of multivariate normality is not satisfied (Awang, 2013).

\section{Results and Discussion}

\subsection{Demographic Statistics}

Male respondents 58\% (81) and female respondents $42 \%$ (59) have found in this study. The t-test shows that there is no means difference between male and female respondents. According to the designation $34.28 \%$ (48) lecturer, $14.28 \%$ (20) senior lecturer, $40 \%$ (56) assistant professor, $3.6 \%$ (5) associate professor, and 7.85\% (11) professor rated on service climate, employee commitment and service quality. Among these faculties, lecturers and senior lecturers rated high on service climate (mean=3.80 and 4.00), employee commitment ( mean $=4.26$ and 4.27), and service quality (mean $=3.86$ and 3.97) respectively. Results indicate that lower level faculties are more committed and they perceived that service climate and service quality are better than mid and high level faculties in private university setting. The interesting finding is that more young faculties are more committed towards their jobs. The last demographic information is salary statistics (Table 4) and this statistics dictate that $79.3 \%$ faculties are earning 20-80 thousand salary and only $20.7 \%$ faculties are earning 80 thousand and above salary per month for normal work load. 


\section{Al Macrothink}

Table 4. Salary Statistics

\begin{tabular}{lllll}
\hline Salary Range & Frequency & Percent & Cumulative Percent \\
\hline \multirow{4}{*}{ Valid } & 20,000 to 50,000 & 65 & 46.4 & 46.4 \\
& 50,000 to 80,000 & 46 & 32.9 & 79.3 \\
& 80,000 to 110,000 & 12 & 8.6 & 87.9 \\
& above 110,000 & 17 & 12.1 & 100.0 \\
& Total & 140 & 100.0 & \\
\hline
\end{tabular}

The core intention of this study is to assess the impact of service climate's dimensions on service quality and also to verify the mediating impact of employee commitment. The results of research are presented below: According to Table 5, the highest mean (3.8607) is related to responsibility dimension of service quality and followed by managerial support (3.7929) and assurance (3.6429). The two lowest mean scores are (3.4314) and (3.4893) related with empathy and job satisfaction respectively. This implies that the higher education institutions should concern more about empathy dimension and job satisfaction of faculty members to improve the service quality.

Table 5. Descriptive Statistics

\begin{tabular}{lllll}
\hline Components & Min & Max & Mean & Std. Deviation \\
\hline WF & 1.75 & 5.00 & 3.5750 & 0.64992 \\
MS & 1.00 & 5.00 & 3.7929 & 0.87272 \\
CO & 1.33 & 5.00 & 3.5583 & 0.79666 \\
JS & 1.38 & 5.00 & 3.4893 & 0.71162 \\
TAN & 1.25 & 5.00 & 3.5667 & 0.73814 \\
REL & 1.80 & 5.00 & 3.6414 & 0.75044 \\
RES & 2.00 & 5.00 & 3.8607 & 0.70089 \\
ASS & 1.50 & 5.00 & 3.6429 & 0.75991 \\
EMP & 1.60 & 5.00 & 3.4314 & 0.76140 \\
\hline
\end{tabular}

According to Table 6, lecturer and senior lecturer are more satisfied than others and mean values are 3.6797 and 3.8000 respectively. Probably, they have less experience about organization and more satisfied about organizational climate. They also rated service quality (SQ) higher than other professors. According to Table 7, all the variables are significantly correlated with service quality (SQ) at $0.001 \alpha$ level. Customer orientation (CO), work facilitation (WF) and job satisfaction (JS) are significantly correlated with SQ also exposing higher values than managerial support (MS). 
Table 6.Group Statistics

\begin{tabular}{ccccc}
\hline Designation & N & SC (Mean) & JS (Mean) & SQ (Mean) \\
\hline Lecturer & 48 & 3.8079 & 3.6797 & 3.8677 \\
Senior Lecturer & 20 & 4.0042 & 3.8000 & 3.9700 \\
Assistant Professor & 56 & 3.3755 & 3.2344 & 3.3179 \\
Associate Professor & 5 & 3.9944 & 3.4250 & 3.7080 \\
Professor & 11 & 3.4672 & 3.4205 & 3.4955 \\
\hline
\end{tabular}

Table 7. Correlations ${ }^{\mathrm{b}}$

\begin{tabular}{ccccccccccc}
\hline Variables & WF & MS & CO & JS & TAN & REL & RES & ASS & EMP & SQ \\
\hline WF & 1 & & & & & & & & & \\
MS & $.511^{* *}$ & 1 & & & & & & & & \\
CO & $.649^{* *}$ & $.318^{* *}$ & 1 & & & & & & & \\
JS & $.687^{* *}$ & $.583^{* *}$ & $.647^{* *}$ & 1 & & & & & & \\
TAN & $.571^{* *}$ & $.387^{* *}$ & $.662^{* *}$ & $.567^{* *}$ & 1 & & & & & \\
REL & $.560^{* *}$ & $.322^{* *}$ & $.688^{* *}$ & $.572^{* *}$ & $.555^{* *}$ & 1 & & & & \\
RES & $.566^{* *}$ & $.393^{* *}$ & $.543^{* *}$ & $.628^{* *}$ & $.489^{* *}$ & $.658^{* *}$ & 1 & & & \\
ASS & $.591^{* *}$ & $.457^{* *}$ & $.702^{* *}$ & $.627^{* *}$ & $.673^{* *}$ & $.667^{* *}$ & $.619^{* *}$ & 1 & & \\
EMP & $.561^{* *}$ & $.552^{* *}$ & $.536^{* *}$ & $.672^{* *}$ & $.543^{* *}$ & $.510^{* *}$ & $.634^{* *}$ & $.632^{* *}$ & 1 & \\
SQ & $.692^{* *}$ & $.513^{* *}$ & $.760^{* *}$ & $.745^{* *}$ & $.793^{* *}$ & $.825^{* *}$ & $.824^{* *}$ & $.867 * *$ & $.810^{* *}$ & 1
\end{tabular}

** Correlation is significant at the 0.01 level

b. List wise $\mathrm{N}=140$

The Table 8 shows that the overall service climate explains $64.3 \%$ variance in service quality because adjusted $R^{2}$ is 0.643 . The correlation of coefficient $(\mathrm{R})$ is 0.803 that means there is a strong relationship exists between overall service climate and service quality.

\subsection{Regression Analysis (Overall service climate)}

Table 8. Model Summary ${ }^{\mathrm{b}}$

\begin{tabular}{llccc}
\hline Model & R & R Square & Adjusted R Square & Std. Error of the Estimate \\
\hline 1 & $.803^{\mathrm{a}}$ & .645 & .643 & .36552
\end{tabular}

a. Predictors: (Constant), SC

b. Dependent Variable: SQ 
The ANOVA Table 9 shows that $\mathrm{F}=250.990$ and it is significant at 0.000 level that means overall service climate as a predictor, predicts significantly service quality (SQ).

Table 9. ANOVA $^{\mathrm{a}}$

\begin{tabular}{lllllll}
\hline Model & & Sum of Squares & Df & Mean Square & F & Sig. \\
\hline \multirow{3}{*}{1} & Regression & 33.533 & 1 & 33.533 & 250.990 & $.000^{\mathrm{b}}$ \\
& Residual & 18.437 & 138 & .134 & & \\
& Total & 51.970 & 139 & & & \\
\hline
\end{tabular}

a. Dependent Variable: SQ b. Predictors: (Constant), SC

The coefficient Table 10 shows the significant relationship between independent variables and dependent variable. The customer orientation (CO) has the highest impact on service quality because its beta value (standardized regression coefficient) is 0.548 , which is higher than work facilitation (WF) and managerial support (MS). Therefore, the customer orientation $(\mathrm{CO})$ is more responsible for explaining variance in the dependent variable (service quality).

Table 10. Coefficients

\begin{tabular}{llllll}
\hline \multirow{2}{*}{ Model } & \multicolumn{2}{l}{ Unstandardized Coefficients } & \multicolumn{2}{l}{ Standardized Coefficients } & \multirow{2}{*}{ Sig. } \\
\cline { 2 - 3 } \cline { 6 - 7 } & $\mathrm{B}$ & Std. Error & Beta & 4.483 & .000 \\
\hline (Constant) & .790 & .176 & .215 & 3.081 & .002 \\
WF & .202 & .066 & .233 & 4.155 & .000 \\
MS & .163 & .039 & .548 & 8.678 & .000 \\
CO & .421 & .048 & & \\
\hline
\end{tabular}

The Table 11 shows the direct link between independent and dependent variables. It is found that all the direct links are significant. Among these three direct links such as customer orientation to service quality, work facilitation to service quality, and employee commitment to service quality achieved the highest absolute beta value $0.761,0.689$, and 0.654 respectively. These values are representing that independent variables such as customer orientation, work facilitation, and employee commitment are more responsible for explaining the dependent variable (service quality). Boshoff and Tait (1996) and Farh, Tsui, Xin, and Cheng (1998) claimed that committed employees were generally deliver high quality service to customers and positively related to sales performance. Our results are consistent with this finding. The Table 12 also shows that customer orientation, managerial support, and work facilitation all have significant influence on employee commitment and $\mathrm{t}=6.414, \mathrm{t}=6.613$, and $\mathrm{t}=6.621$ respectively at 0.000 level. Our results are consistent with Chen (2007) and $\mathrm{He}, \mathrm{Li}$, and Lai (2011). 


\section{Macrothink}

Table 11. Direct link between independent and dependent variable

\begin{tabular}{|c|c|c|c|c|c|c|c|}
\hline Hypothesis & Independent variable & & $\begin{array}{l}\text { Dependent } \\
\text { variable }\end{array}$ & $\begin{array}{l}\text { Standardized } \\
\text { Coefficients, } \\
\text { Beta }\end{array}$ & $\begin{array}{l}\text { Std. } \\
\text { Error }\end{array}$ & $\mathrm{T}$ & Status \\
\hline H1 & Service climate & $\longrightarrow$ & Service quality & 0.803 & 0.050 & 15.843 & Sig. at 0.000 \\
\hline H2 & Service climate & $\longrightarrow$ & Job satisfaction & 0.785 & 0.060 & 14.866 & Sig. at 0.000 \\
\hline H3 & Job satisfaction & $\longrightarrow$ & Service quality & 0.745 & 0.049 & 13.100 & Sig. at 0.000 \\
\hline
\end{tabular}

The Table 12 illustrates that job satisfaction (JS) is partially mediating between service climate (SC) and service quality (SQ). Thus, hypotheses H4 is supporting partially. This finding is consistent with Steinke (2008). The influence of service climate (SC) on service quality (SQ) is reduced when job satisfaction (JS) is incorporated as a mediating variable. Job satisfaction transmits the effect of service climate to service quality. Thus, it can be stated that job satisfaction is a dominant factor to consider for enhancing service quality.

Table 12. Indirect link between independent and dependent variable

\begin{tabular}{|c|c|c|c|c|c|c|}
\hline H & Independent & Mediating & Dependent & $\begin{array}{ll}\text { Direct } & \text { effect } \\
- \text {-No link } & \end{array}$ & $\begin{array}{l}\text { Direct effect } \\
\text {-With link }\end{array}$ & $\begin{array}{l}\text { Mediating } \\
\text { Hypothesis }\end{array}$ \\
\hline $\mathrm{H} 4$ & $\begin{array}{l}\text { Service } \longrightarrow \\
\text { climate }\end{array}$ & $\begin{array}{l}\text { Job } \longrightarrow \\
\text { Satisfaction }\end{array}$ & $\begin{array}{l}\text { Service } \\
\text { quality }\end{array}$ & $\begin{array}{l}\mathrm{SC} \rightarrow(0.803, \\
\mathrm{SQ} \\
\text { sig. })^{* *} \\
\mathrm{JS} \rightarrow \quad \mathrm{SQ} \\
(0.745, \text { Sig. })^{* *}\end{array}$ & $\begin{array}{l}\mathrm{SC} \rightarrow \mathrm{JS} \\
(0.526, \mathrm{sig})^{* *} \\
\mathrm{JS} \rightarrow \quad \mathrm{SQ} \\
(0.297, \mathrm{sig})^{* *} \\
\mathrm{SC} \rightarrow \\
\mathrm{SQ}(0.570, \\
\text { sig)** }\end{array}$ & $\begin{array}{l}\text { Job satisfaction is } \\
\text { partially mediating. }\end{array}$ \\
\hline
\end{tabular}

Note. SC and SQ direct relationship beta value (from 0.803 to 0.570 ) is reduced when the mediator JS is included. Thus, partial mediation is occurred (Awang, 2012, p.17). ** = Significant at $\mathbf{p}=\mathbf{0 . 0 0 0}$ level.

\section{Managerial Implications}

The study will foster managers and practitioners to comprehend the significance of service climate and its components to ensure service quality through building suitable environment in the workplace. Conducive environment is indispensable for employee motivation and innovation. Thus, overall service quality will be improved and automatically performance of the organization will be improved. Furthermore, service climate and its components create image among stakeholders and bring sustainability of the organization. Suitable culture creates value in the products and services through proper nurturing of employees. This study earns an aptness for implications of service climate towards employee satisfaction, service quality improvement, and performance improvement in both the manufacturing and non-manufacturing industries. Job satisfaction is an essential antecedent for superior service quality and performance. A significant number of business entities are searching for 
motivated employees but it is difficult to find due to insufficiency of such a kind. Only, service climate has the hidden power to create motivated employees through job satisfaction. The motivated employees are the asset of workplace and this asset ultimately ensures service quality.

\section{Conclusion}

The objective of the study is to examine the relationship between service climate and service quality in the context of higher education. Also, it has an aim to observe the mediating impact of job satisfaction. The study discloses that the overall service climate has a significant positive impact on service quality. Furthermore, each dimension of service climate has a significant positive impact on service quality. To end, the study reveals that job satisfaction is partially mediating between service climate and service quality. Another interesting point is that customer orientation dimension has the highest impact on service quality because the beta value (0.548) is showing the evidence. Service climate encourages organization commitment to their customers, employees and quest for excellence in delivering quality service. Therefore, a good organization always strives for creating suitable climate and ready to make their customers and employees satisfied to remain competitive. Service climate focuses on customers, employees, and work environment thus it can produce momentum to increase productivity. Service climate determines what level of service quality is important. Employees serve as reporters of what happens in their workplace. Subsequently, employees' reports are validated by customer experiences through service quality.

\section{Limitations and Future Research Directions}

The research contains few limitations such as it was conducted in private-university perspective at Dhaka city only and sample size was not large enough to generalize the results in higher education environment. Moreover, the study included only few private universities from Dhaka city in total of 79 universities in entire country and respondents were faculties of the universities. It is suggested that the future study should incorporate more universities from entire country with sufficient samples in order to generalize the research results. The study is also encouraging other researchers to use this model in different countries in different times. In addition, it would be worthy if service climate as an independent variable, employee commitment as a mediating variable and ethical leadership or quality assurance authority as a moderating variable to judge the impact on service quality in higher education arena. Finally, research could be carried out in other service industries to test the invariance of the proposed model.

\section{References}

Abeldalhi, N., \& Drach-Zahavy, A. (2012). Promoting the patient's care: task engagement as a mediator in the relationship between ward service climate and patient-centered care. Journal of Advanced Nursing, 68(6), 1276-1287. https://doi.org/10.1111/j.1365-2648.2011.05834.x

Anderson, J. C., \& Gerbing, D. W. (1988). Structural equation modeling in practice: a review and recommended two-step approach. Psychological Bulletin, 103(3), 411-23. 
https://doi.org/10.1037/0033-2909.103.3.411

Avcikurt, C., Altay, H., \& IIban, M. O. (2011). Critical success factors for small hotel business in Turkey: An exploratory study. Journal of Cornell Hospitality Quarterly, 52(2), 153-164. https://doi.org/10.1177/1938965509341288

Awang, Z. (2013). Structural Equation Modeling Using AMOS Graphical. Dee Sega Enterprise.

Batt, R. (1999). Work organization, technology, and performance in customer service and sales. Journal of Industrial and Labor Relations Review, 52(4), 539-564. https://doi.org/10.1177/001979399905200403

Blau, P. (1964). Exchange and power in social life. New York, NY: Wiley.

Boo, H. V., Jamil, H., \& Jennifer, T. (2009). Linking service climate to organizational performance: Evidence from Sarawak. International Journal of Business and Society, 10(1), $18-26$.

Boshoff, C., \& Tait, M. (1996). Quality perceptions in the financial services sector: the potential impact of internal marketing. International Journal of Service Industry Management, 7(5), 5-31. https://doi.org/10.1108/09564239610149939

Brown, SP \& Lam, SK. (2008). A meta-analysis of relationship linking employee satisfaction to customer responses. Journal of Retailing, 84(3), 243-255. https://doi.org/10.1016/j.jretai.2008.06.001

Chen, Y. J. (2007). Relationships among service orientation, job satisfaction, and organizational commitment in the international tourist hotel industry. Journal of American Academy of Business, Cambridge, 11(2), 71-82.

Cole, R. E., Bacayon, P., \& White, J. B. (1993). Quality, participation and competitiveness. California Management Review, 35(3), 68-81. https://doi.org/10.2307/41166744

Cook, L. S., \& Verma, R. (2002). Exploring the linkage between quality system, service quality, and performance excellence: Service providers' perspectives. Quality Management Journal, 9(2), 44-56.

Day, G. S. (1994). The capabilities of market-driven organizations. Journal of Marketing, 58(4), 37-52. https://doi.org/10.2307/1251915

Davidson, M. C. G. (2003). Does organizational climate add to service quality in hotels? International Journal of Contemporary Hospitality Management, 15(4), 206-213. https://doi.org/10.1108/09596110310475658

Delgoshayi, B., Tafighi, S. \& Kermani, B. (2008). The relationship between service climate and organizational comfort of the employees and managers of educational hospitals of Hamedan University Health Sciences. Journal of Horizon of Knowledge, 14(4), 60-68.

Dietz, J., Pugh, S. D., \& Wiley, J. W. (2004). Service climate effects on customer attitudes: an 
examination of boundary conditions. Academy of Management Journal, 47(1), 81-92. https://doi.org/10.2307/20159561

Chen, Y. J. (2007). Relationships among service orientation, job satisfaction, and organisational commitment in the international tourist hotel industry. Journal of American Academy of Business, Cambridge, 11(2), 71-82.

Eisenberger, R., Huntington, R., Huntington, S., \& Sowa, D. (1986). Perceived organisational Support. Journal of Applied Psychology, 71, 500-507. https://doi.org/10.1037/0021-9010.71.3.500

Evanschitzky, H. groening, C. Mittal, V. \& Wunderlich, M. (2011). How employer and employee satisfaction affect customer satisfaction: An application to franchise services. Journal of Service Research, 14(2), 136-148.

Farh, J. L., Tsui, A. S., Xin, K. R., \& Cheng, B. S. (1998). The influence of relational-demography and Guanxi: the Chinese case. Organization Science, 9(5), 471-88. https://doi.org/10.1287/orsc.9.4.471

Foley, S. and Hang, Y.N. (2005). The effects of work stressors, perceived organisational support, and gender on work-family conflict in Hong Kong. Asia Pacific Journal of Management, 22, 237-56. https://doi.org/10.1007/s10490-005-3568-3

Francese, P. (1993). Breaking the rules: delivering responsive service. Journal of Hospitality \& Tourism, 16(2), 55-76. https://doi.org/10.1177/109634809301600207

Gazzoli, G., Hancer, M., \& Park, Y. (2010). The role and effect of job satisfaction and empowerment on customers' perception of service quality: A study in the restaurant industry. Journal of Hospitality \& Tourism Research, 34(1), 56-77. https://doi.org/10.1177/1096348009344235

Glisson, C., \& Hemmelgarn, A. (1998). The effects of organizational climate and inter-organizational coordination on the quality and outcomes of children's service systems. Journal of Child Abuse \& Neglect, 22(5), 401-421. https://doi.org/10.1016/S0145-2134(98)00005-2

Glisson, C., \& James, L. R. (2002). The cross-level effects of culture and climate in human service teams. Journal of Organizational Behavior, 23(6), 767-794. https://doi.org/10.1002/job.162

Gouldner, A. W. (1960). The norm of reciprocity: A preliminary statement. American Sociological Review, 25, 161-178. https://doi.org/10.2307/2092623

GroÈnroos, C. (1984). A service quality model and its market implications. European Journal of Marketing, 18(4), 36-44.

Gu, Z., \& Siu, R. C. S. (2009). Drivers of job satisfaction as related to work performance in Macao casino hotels. International Journal of Contemporary Hospitality Management, 21(5), 561-78. https://doi.org/10.1108/09596110910967809 


\section{Macrothink}

International Journal of Learning and Development

ISSN 2164-4063 2017, Vol. 7, No. 3

Hair, J. F. Jr, Black, W. C., Babin, B. J., Anderson, R. E., \& Tatham, R. L. (2006). Multivariate Data Analysis (6th ed.). Prentice Hall, New York, NY.

Hartline, M. D., \& Jones, K. C. (1996). Employee performance cues in a hotel service environment: influence on perceived service quality, value, and word of mouth intentions. Journal of Business Research, 35, 207-15. https://doi.org/10.1016/0148-2963(95)00126-3

He, Y., Li, W., and Lai, K. K. (2011). Service climate, employee commitment and customer satisfaction. International Journal of Contemporary Hospitality Management, 23(5), 592-607. https://doi.org/10.1108/09596111111143359

Hung, T. K. (2006). The impact of human resource management practices on service performance of Taiwanese hotel industry - organizational commitment as a mediator. International Journal of the Information systems for Logistics and Management, 1(2), 109-116.

Jawarski, B. J., \& Kohli, A. K. (1993). Market orientation: antecedents and consequences. Journal of Marketing, 57(1), 53-70. https://doi.org/10.2307/1252057

Joiner, T. A., \& Bakalis, S. (2006). The antecedents of organizational commitment: the case of Australian casual academics. International Journal of Educational Management, 20(6), 439-52. https://doi.org/10.1108/09513540610683694

Kandampully, J., Juwaheer, T. D., \& Hu, H-H. S. (2011). The influence of a hotel firm's quality of service and image and its effect on tourism customer loyalty. International Journal of Hospitality \& Tourism Administration, 12(1), 21-42. https://doi.org/10.1080/15256480.2011.540976

Kenny, D. A., Kashy, D., \& Bolger, N. (1998). Data analysis in social psychology. In Gilbert, D. Fiske, S., \& Lindzey, G. (Eds.). Handbook of social psychology (4th Ed., pp 233-265). New York: Mc Graw Hill.

Khoshnoud, E. (2011). Considering the effect of main dimensions of a job on the commitment of the employees of social provision organization, Sanandaj Branch, MA Thesis, Islamic Azad University, Sanandaj Branch.

Kim, H. J., Tavitiyaman, P., \& Kim, W. G. (2009). The effect of management commitment to service on employee service behaviors: The mediating role of job satisfaction. Journal of Hospitality \& Tourism Research, 33(3), 369-390. https://doi.org/10.1177/1096348009338511

Landrum, H., Prybutok, V., Zang, X. and Peak, D. (2009). Measuring IS system service quality with SERVQUAL: users' perceptions of relative importance of the five SERVPERF dimensions. Informing Science: The International Journal of an Emerging Transdiscipline, 12(14), 17-35.

Lee, Y-K, Nam, J-H, Park, D-H., \& Lee, K. A. (2006). What factors influence customer-oriented prosocial behavior of customer-contact employees? Journal of Services Marketing, 20(4), 251-264. https://doi.org/10.1108/0887604061674599 


\section{Ml Macrothink}

Lehtinen, U., \& Lehtinen, J. R. (1982). Service quality \pm a study of dimensions. Unpublished working paper, Service Management Institute, Helsinki, pp. 439-60.

Lewis, R. C., \& Booms, B. H. (1983). The marketing aspects of service quality in Berry, L.L., Shostack, G. and Upah, G. (Eds), Emerging Perspectives in Service Marketing (pp. 99-107). American Marketing Association, Chicago.

Liao, H., \& Chuang, A. (2004). Transforming service employees and climate: A multilevel, multisource examination of transformational leadership in building long-term service relationships. Journal of Applied Psychology, 92(4), 1006-1019. https://doi.org/10.1037/0021-9010.92.4.1006

Lux, D., Jex, S., \& Hansen, C. (1996). Factors influencing employee perceptions of customer service climate. Journal of Market-focused Management, 1(1), 65-86. https://doi.org/10.1007/BF00129604

Lovelock, C. (2001). A retrospective commentary on the article 'New tools for achieving service quality. Cornell Hotel Restaurant Administration Quarterly, 42(4). https://doi.org/10.1016/s0010-8804(01)80043-4

Malhotra, N., \& Mukherjee, A. (2004). The relative influence of organizational commitment and job satisfaction on service quality of customer-contact employees in banking call centers. Journal of Services Marketing, 18(3), 162-174. https://doi.org/10.1108/08876040410536477

Manning, M. L., Davidson, M., \& Manning, R. L. (2005). Measuring tourism and hospitality employee workforce perceptions. Hospitality Management, 24, 75-90. https://doi.org/10.1016/j.ijhm.2004.05.001

Markovic, S., \& Rasper, S. (2010). Measuring perceived service quality using servqual: a case study of the Croatian hotel industry. Management, 5(3), 195-209.

Maxwell, G. and Steele, G. (2003). Organisational commitment: a study of managers in hotels. International Journal of Contemporary Hospitality Management, 15(7), 368-9. https://doi.org/10.1108/09596110310496006

Mohsin, M., \& Kamal, A. (2012). Managing quality higher education in Bangladesh: Lessons from the Singaporean and Malaysian strategies and reforms. International Journal of Business and Management, 7(20), 59-70. https://doi.org/10.5539/ijbm.v7n20p59

Monem, M., \& Baniamin, M. H. (2010). Higher Education in Bangladesh: Status, Issues and Prospects. Pakistan Journal of Social Sciences (PJSS, 30(2), 293-305.

Morrison, R., Mahamad, O. \& Ramayah, T. (2011). Motivation orientation as an internal marketing tool in service training: A study of service delivery in a hospital. International Journal of Business and Management, 6(2), 93-100.

Mottaz, C. J. (1988). Determinant of commitment. Human Relations, 41(6), 467-82. https://doi.org/10.1177/001872678804100604

Nancarrow, S. (2007). The impact of intermediate care services on job satisfaction, skills, and 
career development opportunities. Journal of Clinical Nursing, 16(7), 1222-1229. https://doi.org/10.1111/j.1365-2702.2007.01355.x

Parasuraman, A., Berry, L. L., and Zeithaml, V. A. (1991). Refinement and reassessment of the SERVQUAL scale. Journal of Retailing, 67(4), 420-50.

Parasuraman, A., Zeithaml, V. A., \& Berry, L. L. (1985). A conceptual model of service quality and its implication for future research. Journal of Marketing, 49(2), 41-50. https://doi.org/10.2307/1251563

Parasuraman, A., Zeithaml, V. A., \& Berry, L. L. (1988). SERVQUAL: a multiple-item scale for measuring consumer perceptions of service quality. Journal of Retailing, 64(1), 12-40.

Parasuraman, A., Zeithaml, V.A. and Berry, L.L. (1994). Alternative scales for measuring service quality: a comparative assessment based on psychometric and diagnostic criteria. Journal of Retailing, 70(3), 201-30. https://doi.org/10.1016/0022-4359(94)90033-7

Peek, R. C. (2003). The relationship between organizational climate and job satisfaction as reported by institution research staff at Florida Community College, Ph.D. Thesis, University of Florida, Gainesville.

Peterson, D.K. (2004). The relationship between perceptions of corporate citizenship and organisational commitment. Business and Society, 43(3), 296-319. https://doi.org/10.1177/0007650304268065

Pierce, J. L., Gardner, D. G., Dunham, R. B., \& Cummings, L. L. (1993). Moderation by organization-based self-esteem of role condition-employee response relationships. Academy of Management Journal, 36(2), 271-288. https://doi.org/10.2307/256523

Robbins, P. S. (2001). Organizational Behavior (9th ed.). Prentice Hall, USA

Rouf, A. M., Habibullah, M. Islam, A. M. (2015). Opinion on the higher education of private universities in Bangladesh. International Journal of Education and Information Technology, $1(3), 80-86$.

Ruo, Y. Z., Xin, M. L., Hai, Z., \& Li, S. (2011). Service climate and employee service performance: exploring the moderating role of job stress and organizational identification. The Service Industries Journal, 31(14), 2355-2372. https://doi.org/10.1080/02642069.2010.503873

Rust, and Oliver, L. (1994). Conceptual issues in the structural analysis of consumption emotion, satisfaction and quality: evidence in a service setting. Advances in Consumer Research, 21, 16-22.

Saffaripour, P., Ayazi, S. and Doayi, M. A. (2010). An analysis of the factors related to job satisfaction and its relationship with service climate among employees of Islamic Azad University, Damavand Branch. Journal of Beyond Management, 15, 145-160.

Salahuddin, \& Aminuzzaman, M. (2011). Quality issues of higher education in Bangladesh. Journal of General Education, 1, 1-15. 


\section{Macrothink}

International Journal of Learning and Development

ISSN 2164-4063 2017, Vol. 7, No. 3

Sargunam, S. S., \& Rathnamala, S. M. (2014). Impact of organizational climate: A study on Anna University affiliated engineering colleges in Tamil Nadu. International Business Management, 8(3), 196-199. https://doi.org/10.3923/ibm.2014.196.199

Shainesh, G. and Sharma, T. (2003). Linkages between service climate and service quality: a study of banks in India. IIMB Management Review, September, 74-81.

Schneider, B., Gunnarson, S. K. and Niles-Jolly, K. (1994). Creating the climate and culture of Success. Organizational Dynamics, 23(1), 17-29. DOI:10.1016/0090-2616(94).90085-X

Schneider, B., White, S. S., \& Paul, M. C. (1998). Linking service climate and customer perceptions of service quality: test of a causal model. Journal of Applied Psychology, 83(2), 150-163. https://doi.org/10.1037/0021-9010.83.2.150

Schnake (1983). An empirical assessment of the effects of effective response in the measurement of organizational climate. Personnel Psychology, 36(4), 791-807. https://doi.org/10.1111/j.1744-6570.1983.tb00513.x

Singh, R. R., Chauhan, A., Agrawal, S., \& Kapoor, S. (2011). Impact of organizational climate on job satisfaction- A comparative study. International Journal of Computer Science Management Studies, 11, 9-18.

Slatten, T., Svensson, G., \& Svaeri, S. (2011). Service quality and turnover intentions as perceived by employees: Antecedents and consequences. Journal of Personnel Review, 40(2), 205-221. https://doi.org/10.1108/00483481111106084

Sofianos, T. (2005). The relationship between organizational climate and job satisfaction as reported by community college executive secretaries (Ph.D. Thesis, University of Florida, Gainesville).

Steinke, C. (2008). Examining the role of service climate in health care. International Journal of Service Industry Management, $19(2), \quad$ 188-209. https://doi.org/10.1108/09564230810869739

Tay, A. (2008). High involvement HRM practice of service corporations in Malaysia: What do employees and supervisors say? Malaysian Management Review, 43(2), 25-38.

Umar, A. (2015). The effect of motivation and career development against employees' performance and job satisfaction of the governor office south Sulawesi province, Indonesia. International Journal of Management Sciences, 5(9), 628-638.

Victoria, B. (2010). The role of learning and customer orientation for delivering service quality to patients. Journal of Health Organization and Management, 24(4), 383-395. https://doi.org/10.1108/14777261011064995 
Appendix

\section{QUESTIONNAIRE}

Please answer the following questions by applying $(\sqrt{ })$ tick mark on a given Likert Scale of 1 to 5 where $\mathbf{1}$ is the least value and $\mathbf{5}$ is the highest value. You need not to assign any scale on the items, which are not included in your choice criteria. Please fill-up the questionnaire honestly based on your own perceptions about your institution. Your invaluable information will be kept confidentially and this is only for research initiative. Only faculty members are encouraged to fill-up.

Your gender:

$\square$ Male $\square$ Female

Please mention your position in the institution:

$\square$ Lecturer $\square$ Senior Lecturer $\square$ Assistant Professor $\square$ Associate Professor $\square$ Professor

Please indicate your salary range based on normal load.

$\square$ Tk. $20,000-50,000 \square$ Tk. 50,000 - 80,000 $\square 80,000-110,000 \square 110,000$ and above 


\begin{tabular}{|c|c|c|c|c|c|}
\hline Work Facilitation & $\begin{array}{l}\text { Strongly } \\
\text { agree }\end{array}$ & Agree & Neutral & Disagree & $\begin{array}{l}\text { Strongly } \\
\text { disagree }\end{array}$ \\
\hline $\begin{array}{l}\text { WF1: I receive adequate support from workmates } \\
\text { to perform my job well. }\end{array}$ & 5 & 4 & 3 & 2 & 1 \\
\hline $\begin{array}{l}\text { WF2: If I perform job well, I receive appropriate } \\
\text { recognition and reward. }\end{array}$ & 5 & 4 & 3 & 2 & 1 \\
\hline $\begin{array}{l}\text { WF3: I have the guidelines and resource } \\
\text { materials available to serve my job. }\end{array}$ & 5 & 4 & 3 & 2 & 1 \\
\hline $\begin{array}{l}\text { WF4: I have access to the product and policy } \\
\text { information when I need them to do my work in } \\
\text { my institution. }\end{array}$ & 5 & 4 & 3 & 2 & 1 \\
\hline \multicolumn{6}{|l|}{ Managerial Support } \\
\hline $\begin{array}{l}\text { MS1: My direct supervisor supports me when I } \\
\text { come up with new ideas on how to improve } \\
\text { service. }\end{array}$ & 5 & 4 & 3 & 2 & 1 \\
\hline $\begin{array}{l}\text { MS2: My direct supervisor encourages me to } \\
\text { deliver high quality service. }\end{array}$ & 5 & 4 & 3 & 2 & 1 \\
\hline $\begin{array}{l}\text { MS3: My direct supervisor is responsive to my } \\
\text { requests for help or guidance. }\end{array}$ & 5 & 4 & 3 & 2 & 1 \\
\hline $\begin{array}{l}\text { MS4: My direct supervisor is very committed to } \\
\text { improving the quality of our area's work and } \\
\text { service. }\end{array}$ & 5 & 4 & 3 & 2 & 1 \\
\hline \multicolumn{6}{|l|}{ Customer Orientation } \\
\hline $\begin{array}{l}\text { CO1: My institution has clear ideas about } \\
\text { students and their needs. }\end{array}$ & 5 & 4 & 3 & 2 & 1 \\
\hline $\begin{array}{l}\text { CO2: High quality service is emphasized as the } \\
\text { best way to keep students. }\end{array}$ & 5 & 4 & 3 & 2 & 1 \\
\hline $\begin{array}{l}\text { CO3: My institution defines its services from } \\
\text { students' perspectives. }\end{array}$ & 5 & 4 & 3 & 2 & 1 \\
\hline $\begin{array}{l}\text { CO4: My institution does a good job of keeping } \\
\text { students informed of changes, which affect them. }\end{array}$ & 5 & 4 & 3 & 2 & 1 \\
\hline $\begin{array}{l}\text { CO5: We are informed about student evaluations } \\
\text { of the quality of service delivered. }\end{array}$ & 5 & 4 & 3 & 2 & 1 \\
\hline $\begin{array}{l}\text { CO6: My institution always responds to the } \\
\text { students' feedback and suggestions quickly. }\end{array}$ & 5 & 4 & 3 & 2 & 1 \\
\hline
\end{tabular}




\begin{tabular}{|c|c|c|c|c|c|}
\hline Job Satisfaction & $\begin{array}{l}\text { Strongly } \\
\text { agree }\end{array}$ & Agree & Neutral & Disagree & $\begin{array}{l}\text { Strongly } \\
\text { disagree }\end{array}$ \\
\hline $\begin{array}{l}\text { JS1: I believe academic staffs of my institution are } \\
\text { well-trained. }\end{array}$ & 5 & 4 & 3 & 2 & 1 \\
\hline $\begin{array}{l}\text { JS2: I believe transparent performance evaluation } \\
\text { system is in practice for academic staffs. }\end{array}$ & 5 & 4 & 3 & 2 & 1 \\
\hline $\begin{array}{l}\text { JS3: I believe performance based reward system is } \\
\text { in practice. }\end{array}$ & 5 & 4 & 3 & 2 & 1 \\
\hline $\begin{array}{l}\text { JS4: I believe academic staffs are enjoying homely } \\
\text { work environment. }\end{array}$ & 5 & 4 & 3 & 2 & 1 \\
\hline $\begin{array}{l}\text { JS5: I believe competitive compensation package } \\
\text { is enjoying academic staffs. }\end{array}$ & 5 & 4 & 3 & 2 & 1 \\
\hline $\begin{array}{l}\text { JS6: I believe supervisors are more concern about } \\
\text { employees' performance. }\end{array}$ & 5 & 4 & 3 & 2 & 1 \\
\hline $\begin{array}{l}\text { JS7: I believe timely and unbiased promotion is a } \\
\text { common practice of my institution. }\end{array}$ & 5 & 4 & 3 & 2 & 1 \\
\hline $\begin{array}{l}\text { JS8: I believe academic staffs are enjoying job } \\
\text { freedom. }\end{array}$ & 5 & 4 & 3 & 2 & 1 \\
\hline \multicolumn{6}{|l|}{ SERVQUAL Dimensions and Items } \\
\hline \multicolumn{6}{|l|}{ Tangibles } \\
\hline $\begin{array}{l}\text { 1. My university has advanced and modern } \\
\text { teaching and IT facilities. }\end{array}$ & 5 & 4 & 3 & 2 & 1 \\
\hline $\begin{array}{l}\text { 2. My university has appealing appearance of } \\
\text { buildings and class rooms. }\end{array}$ & 5 & 4 & 3 & 2 & 1 \\
\hline $\begin{array}{l}\text { 3. Faculty and other staff at my university are } \\
\text { of professional character. }\end{array}$ & 5 & 4 & 3 & 2 & 1 \\
\hline $\begin{array}{l}\text { 4. My university provides interesting and } \\
\text { easy to understand learning materials }\end{array}$ & 5 & 4 & 3 & 2 & 1 \\
\hline \multicolumn{6}{|l|}{ Reliability } \\
\hline $\begin{array}{l}\text { 1. Academics provide fair and consistent } \\
\text { assessment to students work. }\end{array}$ & 5 & 4 & 3 & 2 & 1 \\
\hline $\begin{array}{l}\text { 2. My university shows sincere intention in } \\
\text { resolving students problems }\end{array}$ & 5 & 4 & 3 & 2 & 1 \\
\hline $\begin{array}{l}\text { 3. My university fulfills students' } \\
\text { requirements at the right time }\end{array}$ & 5 & 4 & 3 & 2 & 1 \\
\hline $\begin{array}{l}\text { 4. My university fulfills its } \\
\text { promises/commitments to students }\end{array}$ & 5 & 4 & 3 & 2 & 1 \\
\hline $\begin{array}{l}\text { 5. My university promotes error-free records } \\
\text { and documentations. }\end{array}$ & 5 & 4 & 3 & 2 & 1 \\
\hline \multicolumn{6}{|l|}{ Responsiveness } \\
\hline $\begin{array}{l}\text { 1. My university provides accurate } \\
\text { information regarding timetable, meetings }\end{array}$ & 5 & 4 & 3 & 2 & 1 \\
\hline
\end{tabular}




\begin{tabular}{|c|c|c|c|c|c|c|}
\hline & and events, assignment/exam result, etc. & & & & & \\
\hline & $\begin{array}{l}\text { My university provides prompt } \\
\text { response/feedback to students. }\end{array}$ & 5 & 4 & 3 & 2 & 1 \\
\hline & $\begin{array}{l}\text { Staffs at my university are willing to } \\
\text { provide academic assistance to students } \\
\text { when needed. }\end{array}$ & 5 & 4 & 3 & 2 & 1 \\
\hline & $\begin{array}{l}\text { Staffs at my university are willing to help } \\
\text { students improving their personal and } \\
\text { communications skills. }\end{array}$ & 5 & 4 & 3 & 2 & 1 \\
\hline
\end{tabular}

\begin{tabular}{|c|c|c|c|c|c|}
\hline SERVQUAL Dimensions and Items & $\begin{array}{l}\text { Strongly } \\
\text { agree }\end{array}$ & Agree & Neutral & Disagree & $\begin{array}{l}\text { Strongly } \\
\text { disagree }\end{array}$ \\
\hline \multicolumn{6}{|l|}{ Assurance } \\
\hline $\begin{array}{l}\text { 1. Students are given the professional skills } \\
\text { they require for good academic } \\
\text { performance and employment. }\end{array}$ & 5 & 4 & 3 & 2 & 1 \\
\hline $\begin{array}{l}\text { 2. I am confident that the money students } \\
\text { spent for their degree worth the quality of } \\
\text { education service offered. }\end{array}$ & 5 & 4 & 3 & 2 & 1 \\
\hline $\begin{array}{l}\text { 3. I am confident that administrative staffs } \\
\text { are providing quality services to students. }\end{array}$ & 5 & 4 & 3 & 2 & 1 \\
\hline $\begin{array}{l}\text { 4. Academics at my university are } \\
\text { knowledgeable in their respective areas. }\end{array}$ & 5 & 4 & 3 & 2 & 1 \\
\hline 5. Administrative staffs are courteous. & & & & & \\
\hline \multicolumn{6}{|l|}{ Empathy } \\
\hline $\begin{array}{l}\text { 1. Staffs at my university understand the } \\
\text { range of specific challenges facing } \\
\text { students. }\end{array}$ & 5 & 4 & 3 & 2 & 1 \\
\hline $\begin{array}{l}\text { 2. My university has convenient opening } \\
\text { hours which are well publicized. }\end{array}$ & 5 & 4 & 3 & 2 & 1 \\
\hline $\begin{array}{l}\text { 3. My university provides emergency } \\
\text { services to students. }\end{array}$ & 5 & 4 & 3 & 2 & 1 \\
\hline $\begin{array}{l}\text { 4. My university gives tailored advice to } \\
\text { students on various matters inside and } \\
\text { outside university life. }\end{array}$ & 5 & 4 & 3 & 2 & 1 \\
\hline $\begin{array}{l}\text { 5. Staffs at my university understand the } \\
\text { specific needs of students. }\end{array}$ & 5 & 4 & 3 & 2 & 1 \\
\hline
\end{tabular}

\section{Thanks for your cooperation}

\section{Copyright Disclaimer}

Copyright for this article is retained by the author(s), with first publication rights granted to the journal.

This is an open-access article distributed under the terms and conditions of the Creative Commons Attribution license (http://creativecommons.org/licenses/by/4.0/). 